\title{
@0@
}

Journal of Education, Teaching, and Learning is licensed under

A Creative Commons Attribution-Non Commercial 4.0 International License.

\section{MAXIMIZING INDONESIAN STUDENTS' READABILITY BY USING ENGLISH TEXTBOOKS}

\author{
John Pahamzah ${ }^{1)}$, Syafrizal $^{2)}$, Nurhaedah Gailea ${ }^{3)}$, Zakaria ${ }^{4)}$ \\ ${ }^{1)}$ Universitas Sultan Ageng Tirtayasa, Indonesia \\ E-mail: jhon.pahamzah@untirta.ac.id \\ ${ }^{2)}$ Universitas Sultan Ageng Tirtayasa, Indonesia \\ E-mail: syafrizal@untirta.ac.id \\ ${ }^{3)}$ Universitas Sultan Ageng Tirtayasa, Indonesia \\ E-mail: nurhaedah@untirta.ac.id \\ ${ }^{4)}$ Universitas Sultan Ageng Tirtayasa, Indonesia \\ E-mail: azzam9688@gmail.com
}

\begin{abstract}
The objective of the research was to find out whether the textbook provided by teachers had fulfilled the criteria of having a good book. The researcher used qualitative research, particularly content analysis research design. To answer the research questions, the researcher analyzed the contents of textbooks, evaluated by using a checklist adapted from the Cunningsworth checklist and writing a report. The researcher interpreted data to determine whether the textbook met the criteria for a good textbook. The results of the analysis showed that there were no textbooks that met the criteria for good books. The first result showed that the Think Global Act Locally met the criteria with a percentage of $51.92 \%$, the coverage was $66.67 \%$ for aims and approaches, $33.33 \%$ for design, $40 \%$ for language content, $55.56 \%$ for skills, $66.67 \%$ for topics, $80 \%$ for methodology, $0 \%$ for teacher's book and $75 \%$ for practical considerations. The second was "English on Sky 3" met the percentage of $59.62 \%$, the coverage was $66.67 \%$ for aims and approaches, $50 \%$ for design, $60 \%$ for language content, $72.22 \%$ for skills, $66.67 \%$ for the topic, $80 \%$ for methodology, $0 \%$ for Teacher's book and $50 \%$ for practical considerations. Meanwhile, Practices Your English Competence 3 met the percentage of $42.31 \%$, the coverage was $33.33 \%$ for aims and approaches, $50 \%$ for design, $60 \%$ for language content, $33.33 \%$ for skills, $66.67 \%$ for topics, $60 \%$ for methodology, $0 \%$ for teacher's book and $50 \%$ for practical. In conclusion, there were no criteria that achieved good criteria and three out of eight criteria were considered fair.
\end{abstract}

Keywords: Textbook; Think Global Act Locally; English on Sky 3; Practice Your English Competence 3

\section{INTRODUCTION}

An important component in the implementation of education is the existence of a clear curriculum concept and must be supported by the existence of adequate and easily understood textbooks. Textbooks are important instruments for producing excellent and quality education output. The existence of textbooks is undeniably able to facilitate and streamline the process of delivering learning material delivered by the teacher. But, textbooks sometimes become less desirable reading. There is even an assumption among students that certain textbooks are difficult to understand because the existence of the material is less relevant to the purpose and meaning of the chase. They may contain inauthentic language. Harmer (2007a) stated that good textbook often contain lively and interesting material; they provide a sensible progression of language items, clearly showing what has to be learnt and in some cases summarizing what has been studied so that students can revise grammatical and functional points that they have been concentrating on.

Lately, many English teachers in Indonesia use textbooks as the main source. These teachers who use textbooks as the only one source in their teaching activities treat textbooks like a recipe, a holy book, a compass, a straitjacket, a 
survival kit, a supermarket, and even a crutch (McGrath, 2002). However, some other teachers use them only as supporting media and supplement to enrich their materials. Those who rely heavily on textbooks should give more attention to the process of choosing textbooks. But textbooks can also harm teaching for some reasons. Janssen, Trace, and Kozhevnikova (2012) stated that as we have already said they tend to concentrate on the introduction of new language and controlled work: a teacher relying too heavily on the textbook will often not be encouraged to provide enough roughly-tuned input or output practice. From the statement above, we knew that teachers who relied so much on the use of textbook without using other materials, often found a difficulty to improve their teaching in language. They tended to focus on what was written than to provide other materials that support language teaching.

The inappropriate choice of textbooks will harm the instruction itself, including the students. It will cause some misleading to them, especially students who learn English as a foreign language. The importance of a textbook in the teaching and learning process makes it crucial for the teacher to select the appropriate textbook for the student as there are various English books published by many publishing companies. The teacher needs to be careful in choosing the appropriate one. It is in line with Richards (2010) who stated the teachers should correspond to learners' needs and they should match the aims and objectives of the language learning program. The content has to conform to the current curriculum as well as the aim and goal for students to achieve. No textbook is perfect, for that reason, textbooks analysis is considered a necessity to do. According to Harmer (2007b), textbooks analysis is an outclass judgment on how well the textbook a book has performed in fact. In other words, this process is analysing how appropriate the textbooks can be used in instructions. Textbooks analysis is required to control the mass production of textbooks offers by numerous publishers because the massive market of textbooks is the potential to lead to a condition where the quality of some English textbooks is illegible. The focus of the research is: to identify the fulfilled of the English textbook of Junior High School in Serang Banten to the criteria of an ideal textbook. The researcher is intended to analyse the content suitability of "Think Global Act Locally" textbook published by the centre of curriculum and books (Wachidah, Gunawan, \& Diyantari, 2018), "English on Sky 3", and "Practice Your English Competence 3" published by Erlangga (Zaida, 2018) based on the criteria of EFL evaluation supposed by Cunningsworth (1995).

Several previous studies to measure the students' textbooks readability had been conducted. There was research about textbook readability for primary school textbooks (Kasule, 2010). That research showed that by using the cloze procedure, it was seen that the textbook level was difficult. Besides, there were two previous studies from Langeborg (2010) and Suheri, Azhar, and Afrianto (2018) in a junior high school textbook. Both of them used the Flesch formulas for readability level measuring. Langeborg (2010) had compared the readability level of textbook series and it resulted that each series had different levels. Suheri, Azhar, and Afrianto (2018) investigated that the textbook which they analyzed was at the appropriate level. Meanwhile, in investigating the senior high school students' textbook, there were several studies. The investigation used Flesch formulas as stated in Ghorbanchian, Youhanaee, and Barati (2014) research that compared 279 students' Nelson-Denny test scores and readability by Dale-Chall formulas of seventeen textbooks which had used by the students. Lu (2002) investigated the readability application in reading materials selection and coursebook design for college English in an EFL context in China. It showed that the role of readability was necessary for selecting the materials and the task design for college English.

Thus, from the presented previous study, the readability of textbooks was measured by the formulas. The Reading Ease Formula from Flesch found as the most used formula. It is proved that even though readability formulas are criticized, many researchers still use the formula. Therefore, from the previous studies as mentioned above, there is still some research that analysing the readability of students' textbooks by asking the target reader to measure the readability level. However, based on the concept, the level of readability should be accurate if the text is evaluated by the target reader for the level of readability measuring (Fook \& Alsree, 2010). It means that the present study investigated the readability of students' textbooks by asking the target readers to measure readability level.

Besides, relate to the topic, a textbook is a form of published printed material most commonly used as a teaching and learning media in schools or any educational institution. It is one of the most important media in the learning and teaching process as it serves as a source and guideline to both students and teacher. Brown (2007: 193) stated that a textbook can be simply defined as a book that is used in an educational curriculum; a textbook provides the core materials for a course.

The textbook is one of the most important media for teachers as well as students. By using the textbook, teachers can prepare the teaching material and activities for students systematically because the textbook offers the aims or goals for each lesson. Besides, it can give opportunities to the students in exploring their knowledge and practising their language competence. Therefore, a textbook is one source of materials that can help both teachers and students to do teaching-learning activities in the classroom.

Based on the theory above, it can be concluded the definition of the textbook is a standard book for the study of a particular subject that serves as a source and guideline for teachers and students which contain exercises and reference in the form of the schoolbook, workbook, and coursebook. In this thesis the researcher focus on content analysis of textbook used in Junior High School for ninth grade. Hutchinson and Torres as cited in Richard and Renandya (2002: 83) saw the role of the textbook as a possible agent of change. This can be achieved when definite conditions are met. First, the textbook needs to become a vehicle for teacher and learner training. In other words, besides an explicit and 
detailed teacher's guide, the student book should also include appropriate how-to-learning. Second, the textbook must provide support and help with classroom management, thus freeing the teacher to cope with new content and procedures. Third, the textbook will become an agent of change if it provides the teacher with a clear picture of what the change will look like and clear practical guidance on how to implement it in the classroom. Fourth, if adopted by a school, a textbook can result in collegial support and share responsibility and commitment to the change. It can be concluded that a textbook can help both teacher and learner to reach their aims in language learning, but to the extent where the textbook serve them to reach the goals. It can be accepted if the role of the coursebook is to be at the service of teachers and learners but not to be their master.

Meanwhile, the concept of readability has been defined in various ways. Dubay (2004: 3) argued that readability is what makes some texts easier to read those others. It refers to how easy a written text is to read and understand. The readability of a text is a measure of how well and hoe easily a text conveys the intended meaning to a reader. This implies that when a text cannot be well-read and not easily understood it is unreadable. Good writing should be highly readable to be clearly understood by a wide audience. Readability has the interaction between writers and readers as its central concern as well, in fact, readability research looks exclusively and especially at how readers and writers interact in a text, and it examines ways to enhance and improve factors that connect reader and writer in a text.

\section{Methodology}

The researchers used the qualitative research method by content analysis research design. According to Gall, Gall, and Borg (2007: 300) stated that qualitative research is research which presents facts in narration with words." It means that the finding of this research needed to be more descriptive data rather than numerical and statistical data. It is in line with Fraenkel and Wallen (2009) who stated that qualitative data are collected in the form of words or pictures rather than numbers. The kinds of data are collected in qualitative research include interview transcripts, field notes, photographs, audio recordings, videotapes, diaries, personal comments, memos, official records, textbook passages, and anything else that can convey the actual words or actions of people. In their search for understanding, qualitative researchers do not usually attempt to reduce their data to numerical symbols, but rather seek to portray what they have observed and recorded in all of its detail.

The primary data source of this research was English textbooks used by ninth-grader of Junior High School "Think Global Act Locally" textbook published by the Curriculum (Wachidah, Gunawan, \& Diyantari, 2018), and Book Center "English on Sky 3" textbook published by Erlangga in 2018 (Mukarta et al., 2018), and "Practice Your English Competence 3" textbook published by Erlangga in 2018 (Zaida, 2018). Ary et al. (2010: 29) stated that content analysis focuses on analyzing and interpreting recorded material, which might be in the form of public records, textbooks, letters, films, tapes, diaries, themes, reports, or other documents, this research analyzed the textbooks in terms of Aims and Approaches, Design and Organization, Language Content, Skills, Topic, Methodology, Teachers' Books, and Practical Considerations.

The researcher used a sample from all chapters of English textbooks. The data in this research was collected by identifying the content of the textbook. All chapters in the textbooks were analyzed by all criteria stated by Cunningsworth (1995). Furthermore, the researcher collected the data by reading, understanding, analyzing and collecting data from the book and library.

In analyzing, the data was analyzed using several steps according to Miles, Huberman and Saldana (2014) theories, namely analyzing data in three steps: data reduction, data display, and conclusion. To ensure the credibility and dependability of this study, there were two methods applied. They were consensus and triangulation (Ary et al., 2010: 501).

\section{RESULTS AND DISCUSSION}

The results of the evaluation of each aspect as well as the overall evaluation of the textbook in a percentage were presented in Table I.

TABLE I

TEXTBOOK EVALUATION

\begin{tabular}{lccc}
\hline \multirow{2}{*}{ Evaluation Criteria } & \multicolumn{3}{c}{ Fulfilment } \\
\cline { 2 - 4 } & $\mathbf{T 1}$ & $\mathbf{T 2}$ & $\mathbf{T 3}$ \\
\hline A. Aims and Approaches & $66.67 \%$ & $66.67 \%$ & $33.33 \%$ \\
B. Design and Organization & $33.33 \%$ & $50 \%$ & $50 \%$ \\
C. Language Content & $40 \%$ & $60 \%$ & $60 \%$ \\
D. Skills & $55.56 \%$ & $72.22 \%$ & $33.33 \%$ \\
E. Topic & $66.67 \%$ & $66.67 \%$ & $66.67 \%$ \\
F. Methodology & $80 \%$ & $80 \%$ & $60 \%$ \\
G. Teachers' Books & $0 \%$ & $0 \%$ & $0 \%$ \\
H. Practical Considerations & $75 \%$ & $50 \%$ & $50 \%$ \\
\hline \multicolumn{1}{c}{ Average } & $\mathbf{5 1 . 9 2 \%}$ & $\mathbf{5 9 . 6 2 \%}$ & $\mathbf{4 2 . 3 1 \%}$ \\
\multicolumn{1}{c}{ Criteria } & Sufficient & Sufficient & Poor \\
\hline
\end{tabular}

Table I showed that the first criterion in terms of aims and approaches for textbook 1 and textbook 2 was one of the strengths with the same percentage of $66.67 \%$ or fair category. Almost all the criteria in the aims and approaches were met, such as all material covers everything needed for grade 9 students and provides different teaching and learning styles. While for Textbook 3, this criterion was a weakness, because the material did not meet the needs of students, and textbooks did not meet in terms of the objectives of the teaching program.

The second criterion in terms of design and organizations for Textbook 2 and Textbook 3 has the same percentage of $50 \%$ or sufficient category. Both of these textbooks have strength in terms of the content organized, adequate recycling, and clear layout. With this strength, teachers and students can easily follow the material. As for textbook 1, this criterion was a weakness, because there was no recycling 
for students to easily remember the material that has been given.

The third criterion in terms of language content for Textbook 2 and Textbook 3 has the same percentage of $60 \%$ or fair category. Both of these textbooks have strengths in terms of material for vocabulary teaching. While textbook 1 , this criterion was a weakness with a percentage of $40 \%$ or poor category.

The fourth criterion in terms of skills for textbook 2 has a high percentage of $72.22 \%$ or the fair category. This textbook has the strength in terms of listening skills, there was recording through applications on a smartphone. Whereas textbook 1 has a percentage of $55.56 \%$ or sufficient category, the weakness of this textbook was because there was no recording and listening activities material which help comprehension for students. Textbook 3 has a percentage of $33.33 \%$ or poor category, the weakness of this textbook is the unavailability of material to improve listening and speaking skills.

The fifth criteria in terms of topics for textbooks 1,2 , and 3 have the same percentage of $66.67 \%$ or the fair category. These three textbooks have the same strength. Almost all the criteria in the topic were met, only two criteria were not met. The topics provided were diverse, interesting, close to students' backgrounds, and there is no discrimination in gender, ethnicity, origin, disability, or events.

The sixth criterion in terms of methodology for Textbook 1 and Textbook 3 has the same percentage of $80 \%$ or good category. Meanwhile, for textbook 3 percentages of $60 \%$ is considered fair. Thus, one of the strengths in textbooks 1 and 2 lied in methodology such as making students active in learning, allowing students to present, developing students to communicate so that they can improve their ability to speak in English and giving students to develop responsibilities with learning independently. While for textbooks 3, two out of 5 criteria did not meet, one of them is the lack of material to develop students in communication.

The seventh criterion in terms of teacher's book for Textbook 1, Textbook 2 and Textbook 3 has the same percentage of $0 \%$ or poor category. The main weakness of these textbooks was the unavailability of teacher's books. The teacher's book was important because it provides detailed information about how to use textbooks in teaching and learning activities.

The eighth criterion in terms of a practical consideration. Textbook 1 has the highest percentage of $75 \%$ or the fair category. The strength of this textbook was that it was affordable for students and can even be downloaded free through the website of the Indonesian Ministry of Education and Culture. Meanwhile, textbook 1 and textbook 2 have the same percentage, namely $50 \%$ or sufficient categories. The weakness of this textbook was that it was quite expensive for students because it was printed by the private sector, not by the government.

\section{CONCLUSIONS}

Based on the results, Think Globally Act Locally achieved $51.92 \%$ fulfilment. The achievement showed that the textbook was considered a sufficient textbook. One out of eight criteria was considered good, it was methodology with a percentage of $80 \%$. Three criteria were considered fair, they were Aims and Approaches with a percentage of $66.67 \%$, Topic achieved $66.67 \%$, and practical consideration achieved $75 \%$. One criterion was considered sufficient, it was skilled with a percentage of $55.56 \%$. The rests were considered poor, they were Design and organizations $33.33 \%$, Language content 40\%, and Teacher's Book $0 \%$. English on Sky 3 achieved $59.62 \%$ fulfilment. The achievement showed that the textbook was considered a sufficient textbook. One out of eight criteria was considered good, it was methodology with a percentage of $80 \%$. Four criteria were considered fair, they were Aims and Approaches with a percentage of $66.67 \%$, Language Content $60 \%$, Skill $72.22 \%$, and Topic achieved $66.67 \%$. Two criteria were considered sufficient; they were Design organization and Practical consideration with a percentage of $50 \%$. The rest was considered poor; it was Teacher's Book $0 \%$. The last textbook was Practice Your English Competence 3 achieved $42.31 \%$ fulfilment. The achievement showed that the textbook was considered a poor textbook. There were no criteria that achieved good criteria. Three out of eight criteria were considered fair, they were language content with a percentage of $60 \%$, topic $66.67 \%$, and methodology with a percentage of $60 \%$. Two criteria were considered sufficient; they were Design organization and Practical considerations with the same percentage of $50 \%$. The rests were considered poor, they were Aims and approaches and Skills with a percentage of $33.33 \%$ and Teacher's book with percentage 0 .

\section{REFERENCES}

Ary, Donal. et al. (2010). Introduction to Research in Education: ${ }^{\text {th }}$ Edition. California: Wadsworth.

Brown, H. D. (2007). Teaching by principles: An Interactive Approach to Language Pedagogy ( $3^{\text {th }}$ Ed.). New York: Longman.

Cunningsworth. A. (1995). Choosing your Coursebook. Oxford: Macmillan Heinemann.

Fook, C. Y., \& Alsree, Z. (2010). Computational Text Analysis: A More Comprehensive Approach to Determine the Readability of Reading Materials. Advances in Language and Literary Studies, 200219.

Fraenkel, J. R., \& Wallen, N. E. (2009). How to design and evaluate research in education $\left(7^{\text {th }}\right.$ Ed.). New York: McGraw-Hill.

Gall, M. D., Gall, J. P., \& Borg, W. R. (2007). Educational research: An introduction ( $8^{\text {th }}$ Ed.). Boston: Pearson Education, Inc.

Ghorbanchian, E., Youhanaee, M., \& Barati, H. (2014). A Study of Iranian High School English Textbooks Based on the Standard Criteria. Theory and Practice in Language Studies, 411-422.

Harmer, J. (2007a). How to teach English. Essex: Pearson Education Limited.

Harmer, J. (2007b). The Practice of English Language Teaching ( $4^{\text {th }} e d$.). UK: Pearson Longman. 
Janssen, G., Trace, J., \& Kozhevnikova, L. (2012). A Preliminary Study of Cloze Procedure as a Tool for Estimating English Readability for Russian Students. Second Language Studies, 1-22.

Langeborg, L. (2010). Readability-an Analysis of English Textbooks for Swedish School Years 7-9. Swedia: Akademin för utbildning och ekonomi.

Lu, Z. (2002). Readability in Reading Materials Selection and Coursebook Design for College English in China. Nottingham: University of Nottingham.

McGrath, I. (2002). Materials Evaluation and Design for Language Teaching. Edinburgh: Edinburgh University Press

Miles, M.B, Huberman, A.M, and Saldana, J. (2014). Qualitative Data Analysis, A Methods Sourcebook.

Mukarta, M.S. et al. (2018). English on Sky 3. Jakarta: Erlangga.

Richard, Jack. C. and Renandya, Willy. A. (2002). Methodology of Language Teaching. New York: Cambridge University Press.

Richards, Jack C. (2010). Curriculum Development in Language Teaching. Cambridge: Cambridge University Press.

Suheri, M. D., Azhar, F., \& Afrianto. (2018). A Study on the Text Readability of An English Textbook Entitled Bright: An English Course for Junior High School Students Grade IX Publisher by Erlangga. JOM FKIP, 1-13.

Wachidah, S., Gunawan, A., \& Diyantari. (2018). Think Global Act Locally. Jakarta: Ministry of Education and Culture.

Zaida, Nur. (2018). Practice Your English Competence 3. Jakarta: Erlangga. 